predicted from the physical properties of the coal from which these aggregates were originally derived. For laboratory purposes, samples of coal are distinguished by their power of removing the colour from an aqueous solution of methylene blue and by their relative moisture absorption properties, and it is suggested that the presence in the aggregate of as little as 4 per cent of a coal of the most dangerous class may be sufficient to cause failure.

Investigations made on the setting and maturing movements in breeze and clinker concretes, and on the infiuence of sulphur and of water content, are described, while it is also explained why these aggregates may not be used in reinforced conerete construction owing to the rapid corrosion resulting from their permeability. Of the two tests recommended, the 'pat test' is said to be reliable in the majority of cases. A standard pat is made by mixing a sample of the material under test with fine white plaster of Paris, and a normal Portland cement; if in a period of 1-4 days this exhibits certain defined symptoms of movement, the material is to be judged unsound and must be rejected.

\section{Fossil Algæ in Boghead Deposits}

$\mathrm{B}$ GHEAD coal is a comparatively rare and valuable material yielding gas and paraffin on distillation. It is characterized structurally by the presence of minute 'yellow bodies', the nature of which has been a subject of discussion. An algal nature was suggested for these in 1889 by Edgeworth David, but their peculiar properties in resisting decay and compression prevented any general acceptance of this view. Since that time, reports of C. E. Bertrand and Renault, Zalessky, and Thiessen have supported the algal view, and finally P. Bertrand in 1930 came to the conclusion that the Pila of C. E. Bertrand and Renault was Botryococcus and their Reinschia a member of the Volvocales.

The subject has now been placed on a much surer basis by a detailed study of living Botryococcus Braunii and material from the muds of glacial lakes and more recent peat deposits by Dr. K. B. Blackburn, and a re-examination of the 'yellow bodies' of boghead deposits by Dr. B. N. Temperley (Trans. Roy. Soc. Edin., 58, 1935-36). Dr. Blackburn has followed the alga through its many variations in form; she shows that the inner membranes of the cells are cellulose, but external to this each cell has, towards the periphery of the colony, a cellulose and pectin cap, which contributes to the general mucilage surrounding the colony, whilst towards the centre of the colony, a thick fatty thimble forms around each cell, and these constitute the general matrix of the colony. The cuticular nature of these thimbles would explain their resistance to decay. The cells are rich in oil and also contain appreciable quantities of starch.

Dr. Temperley finds that the 'yellow bodies' described as Pila show extremely close agreement with Botryococcus Braunii, the various polymorphic formas of which are recognizable in the deposits. 'The form Reinschia, formerly ascribed to the Volvocales, differs from Pila in the hollow form of the colonies, but the details of structure correspond so closely with those of Botryococcus that Dr. Temperley concludes that "there is no doubt that the various forms of Reinschia and Pila are fossil colonies of the same type of alga".

\section{Science News a Century Ago}

Medicine in Chili

"The science of medicine has hitherto made but small advances in Chili. . . Twenty years ago medicine was practised by men of colour and the most ignorant quacks, the hospitals were entirely under the control of the monks, and the few well informed physicians, those, namely, who had received an European education found in Lima a more lucrative field for their exertions than was offered to them anywhere in Chili. This state of things, however, no longer obtains, for the number of physicians is now even greater than necessity requires, and there is a college at Santiago at which medicine is taught, although on a somewhat compendious plan. Still there is a scarcity of educated practitioners in the country, where the healing art is chiefly exercised by matrons and old Indian women. The country people are tolerably familiar with the virtues of the rather numerous indigenous plants, but to many of them properties are attributed which the individuals in question do not really possess, and many other remedies supposed to be of great efficacy are solely indebted for the estimation in which they are held to a credulous superstition. When any particular part of the body is the seat of disease, the remedy is sought for in the corresponding part of some animal, variously prepared; thus for ophthalmic disorders the carbonized eyes of birds of prey are administered, the claws of the condor are given for gouty pains of the hands, and the flesh of the smooth-skinned lizard for scurfy affections of the skin." (London Medical and Physical Journal, February 18, 1837.)

\section{The Colony of Western Australia}

Ax a meeting of the Statistical Society held on February 20, 1837, Lord Glenelg, then Colonial Secretary under Lord Melbourne, communicated "A Report of the Committee of Correspondence of the Colony of Western Australia”. Known first as Swan River Settlement, Western Australia was formed into a province in 1829, and the towns of Perth, Freemantle and Guildford were tounded the same year. The development of the colony, however, had been slow. The report consisted of nine sections written by different individuals and dealt with agriculture, live stock, shipping, commerce, population, crime, religion and other matters. The total population of the Swan River Settlements west and east of the Darling Mountains was but 1,550. Sheep farming was the prineipal industry, there being in the York district east of the Darling Hills about 5,000 sheep in excellent condition. The original flocks were imported from "Van Diemen's Land". The animals were a large-framed and very coarsewooled breed, but being crossed with Merino rams, the quality of the wool was constantly improving. The merino flock consisted of about 900 pure descendants of the choice Spanish flock presented in 1791 to George III by the King of Spain. This breed had mouch improved since imported into the colony. The amount of wool shipped for England and the Cape of Good Hope in 1836 was $12,500 \mathrm{lb}$.

\section{The East India Company's S.S. Berenice}

Accordng to The Times, on February 22, 1837, the East India directors gave a dinner at the West 
India Dock Tavern, Blackwall, to Captain Grant and the officers of the S.S. Berenice, which was being prepared to leave for India. This vessel was the first steamship for the East India Company contracted for by the famous engineer and shipbuilder Robert Napier (1791-1876), and her success had much to do with Napier being entrusted with the contracts for the earliest ships of the Cunard Company. The Berenice was $170 \mathrm{ft}$. long by $28.8 \mathrm{ft}$. broad and of 646 tons with engines of 250 nominal horse power. She was a wooden paddle vessel ; her boilers working at a very low pressure were of copper and her engines were of the ordinary side-lever type. Leaving Fal. mouth on March 16, 1837, she reached Bombay on June 13, having called at Santa Cruz, Mayo, Fernando Po, Table Bay and Port Louis. Her average speed was about 8 knots.

\section{Therapeutic Use of Odours}

Ar a meeting of the Medico-Botanical Society on February 22, 1837, reported in the Lancet of March 4, Dr. George G. Sigmond read a paper on odours. Though not now used therapeutically, the older physicians employed them, and, according to Dr. Sigmond, they might once again be found of service in medicine. Travellers, he remarked, who sleep in houses made of cinchona wood, escape intermittent fever, probably from the odour of sulphate of quinine. A similar odour has also relieved tic douloureux. In a work published by a pupil of Linnæus after the death of that eminent botanist, who, however, superintended the construction of the volume, plants were divided into seven classes according to their smells as the aromatica, the fragrantia, etc., each odour having an action peculiar to itself, and some suggestions were made for imparting odours to scentless flowers through the roots, etc.

\section{Davenport's Invention of an Electric Motor}

ON February 25, 1837, Thomas Davenport (1802-5I) secured a patent for an electric motor, the first of its kind taken out in the United States. Davenport was a blacksmith of Brandon, Vermont, who about 1833. with his friend Orange Smalley, began experimenting with magneto machines, unaware of what Henry had already accomplished. By December 1834 they had made a machine having twelve permanent magnets and two electromagnets connected through a form of commutator consisting of wires dipping into mercury cups to an electric battery. By May 1835 he had substituted for the mercury cups insulated segments on the lower part of the wheel shaft, which were rubbed by contact springs made of flattened wire. His new machine he showed to Henry at Princeton, and there saw Henry's own electromagnetic engine.

On Henry's advice, Davenport showed his machine to Alexander Bache and to a group of men at the Franklin Institute, but being short of money, sold it to the Rensselaer Polytechnic Institute for 30 dollars. Encouraged by Prof. Eaton, he made a new machine adapted for traction purposes, and this was exhibited at Troy on October 14, 1835. He was joined by Ransom Cook, and new models were built and exhibited, and Davenport lodged a model and applied for a patent, but at the Patent Office fire of December 15, 1836, both model and papers were destroyed. Soon after this, however, he secured his patent of February 28, 1837, and his model is now preserved in the National Museum at Washington. The inventor, however, reaped no reward for his ingenuity and died on July 6, 1851, on a small farm in Salisbury, Vermont.

\section{Faraday on Marshall Hall}

THE Lancet of February 25 contains the following note on a lecture delivered at the Royal Institution by Prof. Faraday on "Dr. Marshall Hall's Discoveries in the Nervous System": "The principal feature in these discoveries appears to be the fact that in the medulla oblongata and the spinal marrow resides a function which is distinct from sensation and volition, and termed by Dr. Hall the reflex excito-motory function, from its generally proceeding along the nerves from the point of excitement to the spinal marrow, and being reflected from thence to some muscular organ. For this reason the seat of this class of action is called by him the excito-motory system. Müller, of Berlin, Mr. Faraday stated, has in a remarkable manner confirmed the truth of Dr. Hall's discoveries by a recent and separate investigation, although the former still confounds the nature of the function with sensation. ... Mr. Faraday concluded by observing that Dr. Hall's views are original, all preceding physiologists having confounded the phenomena alluded to with sensation. The subject appears to have interested $\mathbf{M r}$. Faraday, as not improbably preparing the way for some future discovery relating to electricity as connected with the nervous system; for, as he said, the division of the nervous system into distinct portions was somewhat simplifying any investigation with regard to electricity, considered as a nervous agent.",

\section{University Events}

Cambridge.-G. E. Briggs, of St. John's College, has been appointed reader in plant physiology.

The Raymond Horton-Smith Prize awarded to that candidate for the degree of doctor of medicine who presents the best thesis for the degree during the year has been divided between Dr. F. Goldby, of Queens' College, and Dr. J. Gray.

Mr. Thomas Dalling has been elected to tho professorship of animal pathology, in succession to Prof. J. B. Buxton, Queens' College, who resigned last term on being appointed principal of the Royal Veterinary College.

Dr. R. G. W. Norrish, formerly fellow of Emmanuel College, H. O. Jones lecturer in physical chemistry, has been elected to the professorship of physical chemistry vacant by the death of Prof. T. M. Lowry.

Oxford.--The Herbert Spencer Lecture for 1937 will be given by Dr. Joseph Needham on May 27 at 5 p.m. in the Examination Schools. The subject is : "Integrative Levels, a Revaluation of the Idea of Progress".

Prof. The Svedberg, of Uppsala, will give two public lectures in English in the Museum, Oxford, at 5 p.m. on February 26 and 11.15 a.m. on February 27 , The subject is: "Sedimentation, Diffusion and Electrophoresis Technique for the Study of HighMolecular Compounds". 